\title{
PENERAPAN MODEL PEMBELAJARAN DISCOVERY LEARNING UNTUK MENINGKATKAN HASIL BELAJAR PADA MATA PELAJARANMATEMATIKA KELAS X MM SMK N I MERBAU
}

\author{
Ponidi ${ }^{1)}$ Marilin Kristina ${ }^{2)}$ Noca Yolanda Sari ${ }^{3)}$ \\ STMIK Pringsewu Lampung \\ Oniponidi@yahoo.com, Marilin_kristina@yahoo.com dan nocayolandasaristmikpsw@gmail.com
}

\begin{abstract}
ABSTRAK
Penelitian tindakan kelas ini dilakukan karena rendahnya hasil belajar siswa kelas X MM SMK N I Merbau pada mata pelajara Matematika. Berdasarkan kenyataan bahwa rendahnya hasil belajar siswa maka penulis mengadakan penelitian tindakan kelas dengan maksud untuk meningkatkan hasil belajar siswa. Penelitian ini dilakukan bersama teman sejawat dengan menggunakan model belajar discovery learning dalam pembelajaran yang dilaksanakan pada siklus I, siklus II, untuk meningkatkan hasil belajar siswa kelas X MM SMK N I Merbau.
\end{abstract}

Rencana perbaikan pembelajaran melalui penelitian ini ternyata dengan menggunakan model belajar coopertive learning dapat meningkatkan hasil belajar siswa. Dari hasil evaluasi dapat terlihat kenaikan prosentase hasil belajar siswa yang dapat mencapai KKM dengan perolehan hasil prosentase pada prasiklus 53\%, siklus I 69\%, dan pada siklus II meningkat menjadi89\% . Dengan demikian penulis merasa perlu untuk menguasai dan menggunakan berbagai model belajar dalam setiap kegiatan belajar di Sekolah.

Kata kunci: Discovery Learning, Hasil Belajar dan Pendidikan Matematika

\begin{abstract}
This class action research was carried out because of the low student learning outcomes of the X MM class of SMK N I Merbau in Mathematics subjects. Based on the fact that the low student learning outcomes, the authors conducted a class action research with a view to improving student learning outcomes. This research was conducted with colleagues using the discovery learning model in learning which was carried out in cycle I, cycle II, to improve student learning outcomes in 10 MM grade students of SMK N 1 Merbau Mataram.
\end{abstract}

The plan to improve learning through this research turned out to be using cooperative learning models to improve student learning outcomes. From the results of the evaluation can be seen an increase in the percentage of student learning outcomes that can achieve KKM with the acquisition of the percentage results in prasiklus 53\%, 69\% in the first cycle, and in the second cycle increased to $89 \%$. Thus the authors feel the need to master and use various learning models in every learning activity in the School.

Keywords: Discovery Learning, Learning Outcomea and Mathematics Educatioan 


\section{A. PENDAHULUAN}

\section{Latar Belakang Masalah}

Sistem pendidikan di indonesia ternyata telah mengalami banyak perubahan. Ini terjadi karena telah dilakukan berbagai usaha pembaharuaan dalam pendidikan. Akibat pengaruh itu pendidikan semakin mengalami kemajuan. Sejalan dengan kemajuan tersebut, maka pendidikan di sekolah-sekolah telah menunjukkan perkembangan yang sangat pesat.

Perkembangan itu terjadi karena terdorong adanya pembaharuan tersebut, sehingga didalam pengajaran pun guru selalu ingin menemukan metode dan peralatan baru yang dapat memberikan semangat belajar bagi murid-murid bahkan secara keseluruhan dapat di katakan bahwa pembaharuan dalam sistem pendidikan yang mencakup seluruh komponen yang ada. Pembangunan dibidang pendidikan barulah ada artinya apabila dalam pendidikan dapat di manfaatkan sesuai dengan kebutuhan.

Pada hakikatnya kegiatan kegiatan belajar mengajar adalah suatu proses interaksi timbal balik antara guru dan siswa dalam satuan pembelajaran. Guru sebagai salah satu komponen dalam proses belajar mengajar merupakan pemegang peran yang asngat penting. Guru bukan hanya sekedar penyampai materi saja, tetapi lebih dari itu, guru dapat dikatakan sebagai sentral pembelajaran.

Sebagai pengatur sekaligus pelaku dalam proses belajar mengajar, gurulah yang mengarahkan bagaimana proses balajar mengajar itu dilaksanakan, karena itu guru harus dapat membuat suatu pengajaran menjadi lebih efektif dan juga menarik sehingga bahan pelajaran yang disampaikan akan membuat siswa merasa senang dan perlu untuk mempelajari bahan pelajaran tersebut.

Berhasilnya tujuan pembelajaran di tentukan oleh banyak faktor diantaranya adalah faktor guru dalam melaksanakan proses belajar mengajar, karena guru secara langsung dapat mempengaruhi, membina, dan meningkatkan kecerdasan serta keterampilan siswa. Guna mencapai tujuan pendidikan secara maksimal peran guru sangat penting dan di harapkanguru memiliki cara atau model mengajar yang baik dan mampu memilih model pembelajaran yang tepat dan sesuai dengan konsep- konsep mata pelajaran yang akan disampaikan.

Diperlukan suatu upaya dalam rangka meningkatkan mutu pendidikan dan pengajaran salah satunya adalah dengan memilih strategi ata cara dalam menyampaikan materi pelajaran agar diperoleh peningkatan prestasi belajar siswa khususnya pelajaran tema pengalamanku. Misalnya dengan membimbing siswa dalam bersama-sama terlibat aktif dalam proses pembelajaran dan mampu membantu siswa berkembang sesuai dengan taraf intelektualnya akan lebih menguatkan pemahaman siswa terhadap konsep-konsep yang diajarkan. Pemahaman ini memerlukan adanya minat dan motivasi. Proses pembelajaran perlu megembangkan adanya medel pembelajaran. Penerapan model pembelajaran Discovery Learning.

Discovery Learning merupakan suatu model pembelajaran yang di kembangkan berdasarkan pandangan konstruktivisme. Model ini menekankan pentingnya pemahaman struktur atau ide-ide penting terhadap suatu disiplin ilmu, melalui keterlibatan siswa secara aktif dalam proses pembelajaran. Model Discovery Learning adalah memahami konsep, arti, dan hubungan, melalui proses intuitif untuk akhirnya sampai pada satu kesimpulan (Budiningsih, 2006:43).

Discovery Learning terjadi bila individu terlibat terutama dalam penggunaan proses mentalnya untuk menemukan beberapa konsep dan prinsip. Discovery Learning dilakukan melalui observasi, klasifikasi, pengukuran, prediksi, penentuan dan inferi. Discovery learning merupakan pembelajaran beraksentuansi ada masalah-masalah kontekstual. Proses ini meliputi proses informasi, transformasi, dan evaluasi. Proses informasi, tahap ini siswa memperoleh informasi mengenai materi yang sedang di pelajari. Pada tahap ini siswa melakukan penyandian atau encoding atas informasi yang di terimanya.

Menurut kemendikbud (materi pelatihan guru implementasi kurikulum 2013:31), discovery learning adalah teori belajar yang di definisikan sebagai proses pembelajaran yang terjadi apabila siswa tidak di sajikan materi pelajaran dalam bentuk final, diharapkan mengorganisasi sendiri.

Model pembelajaran discovery learning menurut Alma dkk (2010:59) yang juga di sebut sebagai pendekatan inkuiri bertitik tolak pada suatu keyakinan dalam rangka perkembangan murid secara independen. Model ini membutuhkan partisipasi aktif dalam penyelidikan secara ilmiah. Hal ini sejalan juga dengan pendapat yang menyatakan bahwa ank harus berperan aktif saat belajar dikelas seperti yang terdapat pada kutipan: "Discovery learning can be defined as the learning that takes place when the student is not presented with subject matter in the final form, but rather is requiredto organize it him self"'(lefancois dalamEmetembun, 1986:103 dalam Dekdikbud 2014).

Menurut Alma, dkk (2010:61) model discovery learning ini memiliki pola strategi dasar yang dapat di klisifikasikan kedalam empat strategi belajar, yaitu: (1) penentuan problem, (2) perumusan hipotesa, (3) pengumpulan dan pengolahan data, dan (4) merumuskan kesimpulan. Menurut kemendikbud (dalam materi pelatihan guru implementasi kurikulum 2013:32).

Model pembelajaran Discovery Learning ini menimbulkan asumsi bahwa ada kesiapan pikiran untuk belajar. Bagi siswa yang kurang pandai akan mengalami kesulitan abstrak atau berfikir atau mengungkapkan hubungan antara konsep- konsep yang tertulis atau lisan sehingga pada gilirannya akan menimbulkan frustasi. 
Model pembelajaran discovery learning ini tidak efisien untuk mengajar jumlah siswa yang banyak, karena membutuhkan waktu yang lama untuk membantu mereka menemukan teori atau pemecahan masalah lainnya. Harapan- harapan yang terkandung dalam metode ini dapat buyar berhadapan dengan siswa dan guru yang telah terbiasa dengan cara-cara yang lama. Model pembelajaran Discovery Learning ini lebih cocok untuk mengembangkan pemahaman, sedangkan mengembangkan aspek konsep, keterampilan dan emosi secara keseluruhan kurang mendapat perhatian. Pada beberapa disiplin ilmu, misalnya kurang fasilitas untuk mengukur gagasan yang dikemukakan oleh para siswa (Syah, 2004: 244).

Penerepan model pembelajaran ini harus mengalami dampak perubahan pada proses hasil belajar. Nana Sudjana (2002:22) hasil belajar adalah kemampuan yang dimiliki siswa setelah ia menerima pengalaman belajarnya. Jadi, hasil belajar merupakan salah satu ukuran penguasaan siswa mendapatkan pelajaran di sekolah. Untuk mengukur kemampuan siswa tersebut dilakukan evaluasi. Evaluasi hasil belajar dapat diartikan sebagai suatu kegiatan pengumpulan data mengenai kemampuan belajar siswa untuk menentukan apakah kompetensi dasar dan indikator hasil belajar tercapai seperti apa yang diharapkan.

Dimyati dan Mujiono (Sesiria, 2005:12) "hasil belajar rmerupakan hasil dari suatu interaksi belajar dan tindakan belajar. Hasil belajar untuk sebagian adalah karena berkat tindakan guru, pencapaian pengajaran, pada bagian lain merupakan peningkatan kemampuan mental siswa". Dari kutipan di atas dapat disimpulkan, bahwa hasil belajar merupakan hasil yang diperoleh siswa setelah siswa tersebut melakukan proses belajar yang melibatkan aspek kognitif, afektif dan psikomotor yang diwujudkan dalam bentuk skor atau angka setelah mengikuti tes.

Hasil belajar adalah hasil yang diperoleh siswa setelah mengikuti suatu materi tertentu dari mata pelajaran yang berupa data kualitatif. Untuk melihat hasil belajar dilakukan suatu penilaian yang bertujuan untuk mengetahui apakah siswa telah menguasai materi atau belum. Penilaian kelas merupakan suatu kegiatan yang dilakukan guru yang berkaitan dengan pengambilan keputusan dan pencapaian kompentensi dasar setelah mengikuti pembelajaran.

Hasil belajar adalah sebuah kalimat yang terdiri dari dua kata yaitu hasil dan belajar. Antara kata hasil dan belajar mempunyai arti yang berbeda. Menurut Djamarah (2004:19), Hasil adalah dari suatu kegiatan yang telah dikerjakan, diciptakan baik secara individu maupun secara kelompok. Sedangkan menurut Mas'ud Hasan Abdul Dahar dalam Djamarah (2004:21) bahwa hasil adalah apa yang telah dapat diciptakan, hasil pekerjaan, hasil yang menyenangkan hati yang diperoleh dengan jalan keuletan kerja.

\section{B. TUJUAN PENELITIAN}

Tujuan dari penelitian tindakan kelas yang dilakukan di kelas X MM SMK N I Merbau ini adalah untuk mengetahui tentang peningkatan hasil belajar terhadap mata pelajaran Matematika.

\section{METODE PENELITIAN}

Penelitian ini menggunakan metodedeskriptif kuantitaif. Pada penelitian diskriptifkuantitatif, peneliti berusaha menggambarkankegiatan penelitian yang dilakukan pada objektertentu secara jelas dan sistematis (Sukardi,2004: 14). Penelitian deskriptif bertujuan untukmemberikan gambaran tentang suatu hubunganantara dua gejala atau lebih (Irawan Soehartono,2008: 35). Metode pengumpulan data dilakukandengan cara :

\section{Dokumentasi}

$\begin{array}{cccr}\text { Metode } & \text { dokumentasi } & \text { yaitu } & \text { mencari } \\ \text { datamengenai } & \text { berbagai } & \text { hal } & \text { yang }\end{array}$ menyangkutcatatan, trankrip, majalah, notulen rapat,agenda, catatan nilai dan sebagainya. Dalam penelitian ini metode dokumentasi diambildari catatan harian pembelajaran, catatankolaborator (mitra penelitian), nilai siswa,maupun catatan perkembangan siswa dalamproses pembelajaran.

\section{Observasi}

Observasi yaitu pengamatan dengan menggunakan indera penglihatan. Metode observasi adalah cara-cara menganalisis dan mengadakan pencatatan secara sistematis mengenai tingkah laku dengan melihat ataumengamati individu atau kelompok secara langsung.

3. Tes

Metode tes digunakan untuk mengukurkemampuan siswa dalam menguasai materipelajaran yang telah diberikan oleh guru.Metode tes dalam penelitian ini diberikansecara bertahap, setelah siswa mengikuti metode-metode pengajaran yang disampaikan oleh guru yang bersangkutan.

\section{ANALISI DATA}

Instrumem

untukmendapatkan data-data yang terukur tentangkompetensi dan ketuntasan belajar siswa padasetiap akhir siklus.

\section{Teknik Kuantitatif}

Teknik analisis data secara kuantitatifdilakukan dengan mengola data hasil penelitianberupa nilai hasil belajar siswa prasiklus, siklus dan siklus II dengan cara ditabulasi, ditentukanreratanya ditentukan pencapai diatas KKM, dan

ditentukan pencapaiannya dibawah KKM.

Rumus yang digunakan dalam penilaian adalah sebagai berikut:

$$
\frac{\text { Jumlah siswa lulus KKM }}{\text { Jumlah siswa }} \times 100
$$

\section{Teknik Kualitatif}

Teknik analisis data secara kualitatifdilakukan dengan mendeskripsikan kondisipeserta didik khususnya pada aktivitas 
bertanyajawab dan berdiskusi dalam proses

pembelajaran. Analisis data kualitatif dilakukansejak sebelum memasuki lapangan, salama dilapangan, dan setelah selesai di lapangan.Langkah selanjutnya ditentukan keabsahannya,kemudian diklasifikasi dan terakhir dilakukaninterpretasi dari data yang diperoleh.

\section{E. HASIL PENILITIAN}

Penelitian tindakan kelas dengan menerapkan metode discoverylearning diharapkan nantinya dapat meningkatkan hasil belajar siswa pada mata pelajaran Matematika pada kelas X MM SMK N 1 Merbau dengan jumlah siswa sebanyak 36 siswa. Pemilihan kelas XI MM karena berdasarkan observasi diawal di temukan masih banyak nilai siswa yang di bawah KKM. Penelitian ini terdiri dari dua siklus yang diawali dengan pra siklus atau kegiatan pendahulu. Prosedur penelitian terdiri dari empat komponen yaitu perencanaan, pelaksanaan atau tindakan, pengamatan, dan refleksi.

Pada tahap pelaksanaan pra siklus telah di hasilkan nilai pada proses pembelajaran di mana proses pembelajaran belum menerapka model pembelajaran discoverylearning. Adapun hasil pembelajaran pada pra siklus dapat di lihat pada tabel di bawah ini.

Tabel 1 Hasil Tes Kondisi Prasiklus

\begin{tabular}{|c|c|c|c|}
\hline No. & Uraian & $\begin{array}{c}\text { Latihan } \\
\text { Soal }\end{array}$ & Keterangan \\
\hline 1. & Nilai terendah & 40 & \multirow{4}{*}{$\begin{array}{l}\text { Dari } 36 \text { siswa sebanyak } 19 \\
\text { siswa }(53 \%) \text { telah mencapai } \\
\text { nilai KKM atau sudah } \\
\text { tuntas, sedangkan } 17 \text { siswa } \\
(47 \%) \text { belum mencapai } \\
\text { KKM atau belum tuntas. }\end{array}$} \\
\hline 2. & Nilai tertinggi & 75 & \\
\hline 3. & Nilai rata-rata & 60 & \\
\hline 4 & Persentase Ketuntasan & $53 \%$ & \\
\hline
\end{tabular}

Sumber: Hasil belajar siswa kelas X MM

Berdasarkan data hasil observasi pra siklus diatas presentase ketuntasan baru mencapai 53\%, sedangkan jumlah siswa yang telah mencapai KKM hanya 19 siswa dari 36 siswa. Sehingga hasil belajar belum mencapai target yang diharapkan yaitu $85 \%$ ketuntasan siswa.

Berdasarkan kegiatan refleksi dan observasi, peneliti bersama supervisor 2 berpendapat bahwa rendahnya hasil belajar siswa pada mata pelajaran matematika disebabkan karena pembelajaran yang dilakukan guru kurang berkualitas, kurang menantang siswa dan kurang menyenangkan, dan pembelajaran masih berpusat pada guru (teacher centred) serta pembelajaran masih bersifat abstrak tanpa menggunakan alat peraga. Berdasarkan data tersebut maka penelitian perlu dilakukan ke tahap siklus 1 dengan menggunakan metode discovery learning.

Adapun hasil dari penelitian pada proses pembelajaran di siklus ke I dapat di lihat pada tabel di bawah ini:
Tabel 2 Hasil Tes Kondisi Siklus I

\begin{tabular}{|c|c|c|c|}
\hline No. & Uraian & $\begin{array}{c}\text { Latihan } \\
\text { Soal }\end{array}$ & Keterangan \\
\hline 1. & Nilai terendah & 50 & \multirow{4}{*}{$\begin{array}{l}\text { Dari } 36 \text { siswa sebanyak } 25 \\
\text { siswa }(69 \%) \text { telah mencapai } \\
\text { nilai KKM atau sudah } \\
\text { tuntas, sedangkan } 11 \text { siswa } \\
(31 \%) \text { belum mencapai } \\
\text { KKM atau belum tuntas. }\end{array}$} \\
\hline 2. & Nilai tertinggi & 78 & \\
\hline 3. & Nilai rata-rata & 70 & \\
\hline 4 & Persentase Ketuntasan & $69 \%$ & \\
\hline
\end{tabular}

Sumber: Hasil belajar siswa kelas X MM

Berdasarkan data hasil observasi siklus I diatas presentase ketuntasan baru mencapai 69\%, sedangkan jumlah siswa yang telah mencapai KKM hanya 25 siswa dari 36 siswa. Sehingga hasil belajar belum mencapai target yang diharapkan yaitu $85 \%$ ketuntasan siswa.

Berdasarkan kegiatan refleksi dan observasi, peneliti bersama supervisor 2 berpendapat bahwa rendahnya hasil belajar siswa pada mata pelajaran matematika disebabkan karena pembelajaran dengan menerapkan model discoverylearning masih belum maksimal. Sehingga target yang di harapkan belum mencapai. Berdasarkan data tersebut maka penelitian perlu dilakukan ke tahap siklus II dengan menggunakan metode discovery learning yang lebih maksimal lagi.

Adapun hasil dari penelitian pada proses pembelajaran di siklus ke II dapat di lihat pada tabel di bawah ini:

Tabel 3 Hasil Tes Kondisi siklus II

\begin{tabular}{|c|c|c|c|}
\hline No. & Uraian & $\begin{array}{c}\text { Latihan } \\
\text { Soal }\end{array}$ & Keterangan \\
\hline 1. & Nilai terendah & 60 & \multirow{4}{*}{$\begin{array}{l}\text { Dari } 36 \text { siswa sebanyak } 32 \\
\text { siswa }(89 \%) \text { telah mencapai } \\
\text { nilai KKM atau sudah } \\
\text { tuntas, sedangkan } 4 \text { siswa } \\
(11 \%) \text { belum mencapai } \\
\text { KKM atau belum tuntas. }\end{array}$} \\
\hline 2. & Nilai tertinggi & 80 & \\
\hline 3. & Nilai rata-rata & 76 & \\
\hline 4 & Persentase Ketuntasan & $89 \%$ & \\
\hline
\end{tabular}

Sumber: Hasil belajar siswa kelas X MM

Berdasarkan data hasil observasi siklus II diatas presentase ketuntasan baru mencapai $89 \%$, sedangkan jumlah siswa yang telah mencapai KKM 32 siswa dari 36 siswa. Sehingga hasil belajar sudah mencapai target yang diharapkan yaitu $85 \%$ ketuntasan siswa.

Berdasarka hasil penelitia tindakan kelas yang di dapat pada sikus ke II ini, peneliti bersama kolaborator sepakat untuk mengakhiri proses pembelajaran karna hasil yang di harapkan sudah mecapai ketuntasan yang di targetkan.

\section{F. PEMBAHASAN}

Pada kondisi prasiklus, guru masih menggunakan metode konvensional yaitu menggunakan metode cermah, dan media papan tulis. Proses pembelajaran berjalan dengan pasif. Siswa hanya duduk dan diam mendengarkan dan terlihat sebagian besar Siswa mengalami rasa takut. Sejumlah siswa belum mampu melontarkan pertanyaan dan juga menjawab pertanyaan dari guru, hanya beberapa siswa sudah terlihat berani 
bertanya dan menjawab pertanyaan guru walaupun masih ada beberapa pertanyaan yang keluar dari konteks materi. dari hasil wawancara dengan beberapa speserta didik, ternyata cara guru dalam menyampaikan materi membuat mereka bosan dan tidak tertarik dengan materi tersebut.

Adanya kondisi belajar yang didapatkan di proses pembelajaran yang telah berlangsung membuat peneliti untuk melakukan tindakantindakan perubahan dalam proses pembelajaran. Adapun tindakan perubahan belajara dengan menerapkan model pembelajaran Discovery Learning. Model ini telah di terapkan dalam proses pembelajaran baik pada siklus I maupun siklus II untuk melakukan perubahan terhdapa hasil belajar.

Proses penerapan pembelajaran dengan mengunakan model belajar Discovery Learningdapat berhasil dalam meningkatka hasil belajar siswa. Hasil belajar di setiap siklusnya ini terdapat perubaha pada nilai rata-rata. Adapu hasil tersebut dapat di lihat pada tabel di bawah ini:

Tabel 4 Perbandingan Hasil Belajar dari nilai rata-rata pada Prasiklus, Siklus I, dan Siklus II

\begin{tabular}{|c|c|c|}
\hline $\begin{array}{c}\text { Rata-rata Kondisi } \\
\text { Prasiklus }\end{array}$ & Rata-rata Siklus I & Rata-rata Siklus II \\
\hline 60 & 70 & 76 \\
\hline
\end{tabular}

Sumber: hasil belajar siswa

Berdasarkan hasil penelitian, jika guru menggunakan metode discovery learning dalam pembelajaran matematika maka hasil belajar siswa akan meningkat. Hal ini bisa dibuktikan dengan kemajuan hasil belajar siswa setelah menggunakan metode discovery learning. Peningkatan tersebut dapat terlihat dari nilai dan presentase nilai siswa dari tabel-tabel diatas. Dari tabel tersebut jelas sekali perbedaannya nilai rata-rata dari kondisi pra siklus, siklus 1, dan siklus II.

\section{G. KESIMPULAN}

Kesimpulan dari penelitian tindakan kelas berdasarkan hasil analisis data pada bab sebelumnya, terkait dengan penerapan model pembelajaran Discovery Learning terhadap hasil belajar siswa, maka diperoleh beberapa kesimpulan sebagai berikut:

1. Penerapan pembelajaran Discovery Learning dapat meningkatkan hasil belajar pada pelajaran matematika siswa kelas X MM

2. Peningkatan hasil belajar siswa pada mata pelajaran Tematik dapat dibuktikan dengan adanya presentase pra siklus 53\% hnaya 19 siswa yang tuntas dari jumlah siswa 36, meningkat menjadi $69 \%$ pada siklus 1 dengan jumlah siswa yang tutas mencapai 25 siswa, dan mengalamai peningkaran menjadi $89 \%$ pada siklus II dengan jumlah siswa yang tuntas mencapai 32 siswa.

3. Peningkatan hasil pembelajaran juga dapat terlihat dari adanya perbedaan pada nilai ratarata yang mengalami perubahan, dimana pada pra siklus nilai rata-rata hanya mencapai 60 , dan pada siklus I mencapai 70 kemudian meningkatkan lagi pada siklus II menjadi 76.

\section{DAFTAR PUSTAKA}

Alma, dkk. (2010). Pembelajaran Kooperatif. Jakarta: Dirjen.

Budiningsih. (2006). Blogspot Discovery Learning. $\begin{array}{llll}\text { Diunduh } & 20 & \text { April } & 2019\end{array}$ darihttp://Akhmadsudrajat.wordpress.com/ 2008/01/12/Discovery Learning

Depdikbud, 2014. Kurikulum KTSP Standar Kopetensi Mata Pelajaran Matematika Untuk SD/MI, Jakarta.

Djamarah. (2004). Proses Pembelajaran Mengajar. Jakarta: Bumi Aksara.Jakarta: Rineka Cipta.

Irawan Soehartono. (2008). Metode penelitian sosial. Bandung: Remaja Rosdakarya.

Kemendikbud. (2013). Kurikulum Standar Kopetensi Mata Pelajaran Matematika Untuk SD/MI, Jakarta.

Nanna Sudjana. (2002). Teknologi Pengajaran. Bandung: Sinar Baru Algensindo.

Sesiria. (2005). Evaluasi Hasil Belajar. Surakarta: Pustaka Pelajar.

Sukardi. (2004). Metodologi penelitian pendidikan. Jakarta: Bumi Aksara.

Syah. (2004). Model Pembelajaran Kooperatif. Panang: UNP. 